\title{
Resistance to Accounting for Outcomes: A Case Study of the Egyptian Sales Tax Department
}

\author{
Dr. Ahmed Othman Rashwan Kholeif \\ Assistant Professor in Accounting \\ Department of Accounting \\ Faculty of Commerce \\ Alexandria University
}




\title{
Resistance to Accounting for Outcomes: A Case Study of the Egyptian Sales Tax Department
}

\begin{abstract}
Recent years have witnessed the growth of monitoring and evaluation activities in the work of supranational organisations and, therefore, the globalisation of the concept of the audit society. This paper examines a failed attempt by the World Bank to institutionalise an alternative monitoring and evaluation (M\&E) system to account for outcomes as a condition of funding in an Egyptian case study. It questions the claims of the Wold Bank about the cause of the failure of the new M\&E system to understand the reasons for resistance to accounting for outcomes. Longitudinal case study data were collected from interviews, observations, discussions and documentary analysis, and from publicly available reports and other media issued by the World Bank. The official explanation for the failure to implement outcomes based budgeting in Egypt was obstruction by middle managers. The findings of this study provide an alternative explanation to that published by the World Bank for the failure to institutionalise outcomes based budgeting in Egypt over the last decade. It was found that the middle managers were the real supporters of performance-based budgeting (PBB). Other parties and existing laws and regulations contributed to the failure of the $\mathrm{PBB}$ project. In the absence of the direct involvement of international experts, the World Bank local consultants authorised the reproduction of existing budgeting rules and routines. The Budget Law and the Ministry of Finance acted as an obstacle and legitimated the use of PBB as a complementary tool. The IT developers spent the World Bank's funds on automating the accounting systems that support the institutionalised line item budgeting. The resignation of key champions who initiated and supported the implementation of PBB resulted in the official termination of the new budgeting system. This case and similar cases may enhance our understanding of how and when monitoring and evaluation technologies should be introduced at the global level, in order to manage conflicts of interest between agencies and beneficiaries.
\end{abstract}

Keywords - Accountability, Performance/Outcomes Based Budgeting, Resistance, Egypt. 


\section{Resistance to Accounting for Outcomes: A Case Study of the Egyptian Sales Tax Department}

\section{Introduction}

Accounting for outcomes can be seen as one aspect of the 'audit explosion' (Power, 1994; 2003) that in recent years has seen the growth of monitoring and evaluation activity in a wide range of areas including the measurement of public service performance, environmental audit, value for money audit, management audit, forensic audit, and quality audit (Berry and Gray, 2000; Bowerman et al., 2000; Manson et al., 2001; Power, 2003; Hughes, 2005; Khalifa et al., 2007; Roberts, 2009; Kilfoyle and Richardson, 2011; Adhikari et al., 2013; Brunt, 2014; Malmmose, 2015). Power (2000) argues that these have arisen from a commitment to organizational and financial reform in public sector institutions, the political demands for greater accountability and transparency of service providing organisations and the rise of quality assurance practices and related transformation in regulatory style. However, he also states that "the ideas of the "audit society" and of the "audit explosion" require a great deal more conceptual and empirical work...it remains to be seen how well this argument travels to other countries and systems'(Power, 2000: 112 \& 114).

The World Bank has required the development of monitoring and evaluation (M\&E) systems in beneficiary governments since the 1980s and during the period c.1999-2007, following pressure from US Congress for greater transparency within the World Bank itself[1]. This became a more concrete requirement for governments to put in place accounting technologies such as outcomes or performance based budgeting as a condition of lending[2] (Kamarck, 2003; Kusak and Rist, 2004; Bruel and Moravitz, 2007; BeckettCamarata, 2009; Margi, 3013).

In 2000, the World Bank launched their general programme aimed at strengthening results-based monitoring and evaluation for itself and its borrowers (Kusak and Rist, 2004), and the Egyptian Ministry of Finance expressed a desire to participate in the programme as a pilot study designed to introduce a more results oriented budget process in selective agencies (World Bank, 2001). The proposal became an agreement to implement performance based budgeting (PBB) throughout the ministry, using the Egyptian Sales Tax Department (ESTD) as one of the pilot studies (Kusak and Rist, 2004). The project though was attached to funding from the World Bank to reform the computerised tax collection systems in the department and began in 2002-3. 
As a case study of custom developed accounting software implementation, this is a success story with substantial increases in taxation collected being shown, but PBB was not implemented, though some elements of M\&E were established. Later World Bank documents blame difficulties and obstacles raised by middle managers for the failure of the PBB project (Mackay, 2007; Schiavo-Campo, 2005; Hassanein, 2005). For example, Mackay (2007: 61) observes that 'Yet efforts to institutionalize M\&E in Egypt have been substantially frustrated by mid-level officials who did not buy into this vision of an M\&E system'. WBOED (2004: 59) concludes that 'the process has been entirely top-driven. There is no evidence of meaningful participation by staff...the staff reaction has varied from inattention to resistance'.

The aim of this paper is to question World Bank claims that obstructive middle management is the cause of the failure of PBB to be institutionalised in the Egyptian project. As it is often observed that accounting systems and practices are difficult or slow to change (Scapens and Roberts, 1993; Burns, 2000; Granlund, 2001; Burns et al., 2003; Dambrin et al., 2007; Lukka, 2007; Macintosh et al., 2009; Kilfoyle and Richardson, 2011; Adhikari et al., 2013; Brunt, 2014; Robalo, 2014; Malmmose, 2015), the question is how and why middle managers in the case study choose to resist the move to $\mathrm{PBB}$, ending up producing stability and/ or outright status quo. The task here is to unpick the context around a somewhat prosaic (and ironic) case of resistance to globally-driven management accounting change in terms of accountability for outcomes or PBB.

The remainder of this paper is organised into five sections. The next section reviews the accounting literature focussing on resistance to globally driven accounting change. After the outline of research methods, the paper presents the case analysis and in the discussion section, the paper compares and contrasts the researcher' findings with the World Bank claims and reflects on why the two sets of research diverge and policy implications. The final section provides some conclusions within the overarching theme of the diffusion (or perhaps contagion) of the 'audit society'.

\section{Literature Review}

It is widely recognised that change to accounting and accountability practices is globally driven (e.g. Granlund and Lukka, 1998; Cooper et al., 2003; Graham and Neu, 2003; Sikka, 2003; Unerman, 2003; Nolke, 2005; Chanda \& White, 2007; Adhikari et al., 2014). Granlund and Lukka (1998: 
170), for example, conclude that 'current management accounting practices are strongly framed and driven by factors at the macro level, at which various and considerable global pressures of convergence currently are at work.' Graham and Neu (2003: 451) also observe that 'the propagation of accounting changes ... has become more and more associated with supranational organizations, rather than with agencies of individual states.' Supranational organisations such as the World Bank encourage and facilitate the diffusion and reproduction of specific accounting and accountability practices across time and space thereby contributing to the globalisation of monitoring and evaluation practices. For example, Neu et al. (2002) examine how the World Bank operates as a coordinating agency within the field of higher education and how its specific financial technologies operate as the carries of globalisation practices.

Since 2000, the World Bank has worked actively through its mechanisms to diffuse and institutionalise results-based monitoring and evaluation practices around the world (Mackay, 2007). This supranational organization not only governs the activities in distant sites but encourages the diffusion of standardized practices across sites. Graham and Neu (2003: 452) claim that 'accounting technologies within supranational organizations help create and sustain the non-equilibrium conditions that persist between the centre and the periphery, between non-majority and majority worlds'. By adopting and diffusing results-based monitoring and evaluation practices, the World Bank extends the idea of the 'audit society' to the global level. Power (2000: 114) argues that ' $[\mathrm{t}]$ he hunch behind The Audit Society is that the design of accounting reports, and of the performance measures by which organisations can be judged, is greatly influenced by the imperative of "making them auditable", and that this has much to do with agendas for control of these organisations'. For example, in a report on an IMF budgetary reform project in Russia, the implementation of outcomes based budgeting in government was hindered by the lack of capacity of government audit, but continued with the intention of full audit taking place in future (Diamond, 2002).

The whole point of output based measurements in the public sector is to increase the auditability and accountability of individuals and governments. It also provides both legitimation and rewards for their achievements, and the potential for sanctions (Breul and Moravitz, 2007; Beckett-Camarata, 2009; Margi, 3013). Mackay (2006), writing on behalf of an independent evaluation group of the World Bank, examines the institutionalization of M\&E systems undertaken by the World Bank. He identifies 'huge changes' in the previous 10 years and states that 'There are a growing number of 
countries with strong M\&E systems, with a more committed set of stakeholders including government ministers, senior officials, donors and academia, and with well-functioning evaluation associations' (p.15).

However, there are difficulties and issues, not least with African countries which lack the resources and infrastructure to implement M\&E systems. Many countries are 'simply too poor to be able to conduct evaluations and reviews, relying instead on donors for such work' (MacKay, 2006, p.13). The supply side for M\&E systems, as he puts it, is much stronger than the demand side. The World Bank can supply expertise but Mackay (2006) also points out that a great extent they are themselves gaining experience from the countries they have worked with so far, implying that there is a significant level of experimentation by the supranational bodies in implementing $M \& E$ systems. Common mistakes involve over-engineering, lack of a 'champion', poor IT and lack of an audit strategy.

This research project is an investigation into the pilot study to introduce performance based budgeting in the ESTD in Egypt. The pilot study itself is an interesting case in the difficulties of embedding performance based budgeting when it is not the primary aim and objective of the organisation concerned. However, the full significance of the case cannot be understood without the knowledge that this project was part of a much larger scale modernisation project at government level. The modernisation programme cannot be fully understood without the knowledge that it was funded by the World Bank and that one of the conditions of funding was the introduction of monitoring and evaluation across government. This case does, in fact, appear in World Bank publications that review its global monitoring and evaluation programme. The ESTD case has become notorious in World Bank folklore as a failure due to the intransigence of the middle managers.

To understand how and why middle management resists the World Bank's pressures to implement PBB in the ESTD, we refer to a number of previous studies that has documented the reasons for resistance to change in management accounting practices (Scapens and Roberts, 1993; Burns, 2000; Granlund, 2001; Burns et al., 2003; Dambrin et al., 2007; Lukka, 2007; Hyvonen et al., 2009; Macintosh et al., 2009; Kilfoyle and Richardson, 2011; Adhikari et al., 2013; Brunt, 2014; Robalo, 2014; Malmmose, 2015). In an early example of such studies Ouibrahim and Scapens (1989) identify a complex web of factors contributing to the failure of management accounting systems. One factor was the use of production language as the means of communication between managers, who did not respond to a perceived imposition accounting language into practices. The introduction 
of new accounting systems also threatened the autonomy of site managers, who drew on a variety of resources to resist the introduction of new systems.

Burns and Scapens' (2000) found that unsuccessful change process in an engineering division were due to contradictions between new management accounting rules and existing routines and institutions. Resistance to change as adherence to earlier procedures or routines is also observed in Granlund (2001), where he concludes that different human, institutional and economic factors are intertwined in the cumulative change process or its denial. New rules and routines that are introduced without corresponding institutional change also tend toward failure, as do those introduced without changes in communication patterns and structures.

Burns et al (2003) observe that an economic value added (EVA) system implemented to replace a previous performance measurement system based on profit margins was suspended six months later due to conflicts between accountants and managers. The latter felt that there were contradictions between the existing (sales- and margins-based) institutions and the new rules associated with EVA, given no change in actual practice in the retail environment in which they operated. In a second case, Burns et al. (2003) explore the difficulties facing the accounting change that challenges existing ways of thinking. A new accountability system is introduced to a product development department, with the aim of making the chief chemist, the head of the department, more result-oriented. However, the new emergent routines have a negligible impact on the ways the chief chemist and his staff think about the nature of their activities as the new accountability system is not passed down from the chief to his staff members.

Dambrin et al. (2007) investigate the institutionalisation process of management control systems in a French subsidiary of a pharmaceutical laboratory. They argue that the process by which institutional changes are implemented inside organisations and the process of decoupling are two aspects of the same issue. Results of their study highlight how discourses of organisational actors contradict new ideas and control techniques. Adhikari et al. (2013) also study the dissemination and institutionalization of public sector accounting reforms in Nepalese and Sri Lankan central governments. Empirical findings show increasing resistance to accounting changes at the lower administrative level in both countries which demonstrates a need to understand the contexts of less developed countries and to fulfil basic preconditions prior to disseminating reforms there. 
Robalo (2014) conducts a longitudinal case study within a Portuguese public sector organisation, the National Postal Service of Portugal, where management accounting innovations, income statements and key performance indicators, were implemented. Findings of the study indicate that trust and power issues should analysed simultaneously to extend our understanding of how management accounting innovations are (or are not) used in practice. They also provide evidence that external and internal pressures or the lack of them should be considered through time. Brunt (2014) examines also accounting change in local governments. He studies the link between corporate-level interventions and the patterns of value creation at street-level. Findings reveal that corporate and street-level interventions are unique dimensions to signify the multiple patterns of accounting change in local governments. Malmmose (2015) is another example of investigating a management accounting reform in public services. She studies the development of the polarised discourses of management accounting and the medical profession during the introduction of a new public management reform in the public health care in Denmark. Results show that management accounting discourse becomes the dominating ideology which is embedded in the public rhetorical debate.

\section{Research Methods}

The data collection included unstructured and semi-structured interviews, site visits and the collection of documentary evidence. 35 interviews were conducted with 22 interviewees, with interviews generally lasting between 1 and 2 hours. The total length of the interviews is about 60 hours. The work here emerged as an interesting study into the implementation of a performance based budgetary system. The researcher was therefore not present in the organization throughout the three years but made a number of visits. Data on the use of accounting for outcomes in the World Bank was conducted through publicly available secondary sources and through a literature review.

Interviews were conducted with most members of the PBB project team, including accountants, IT developers and top, middle and line-managers. Other data collection methods used include background questionnaires, direct and participative observations, including group meetings with PBB project team, financial accounts and budgets. Using materials collected from various sources, this study proceeds to triangulate the field data used, enabled what Scapens (1990) calls 'contextual validity', the triangulation of evidence by collecting different evidence on the same research issue, 
collecting other evidence from the same source and working in teams in order to reach an agreed interpretation of a particular case.

General sales tax was introduced in Egypt on 3 May 1991 to replace consumption taxes as part of an overarching World Bank/IMF Economic Reform and Structural Adjustment Programme. The Egyptian Sales Tax Department (ESTD) became a revenue generating division of the Ministry of Finance with its headquarters based in Cairo but covering 23 Regions, with 81 Districts and 25 Offices in total. In 2003/2004, the ESTD reported sales tax revenues of more than L.E. 22 billion (approximately more than $\$ 3.5$ billion). In 2007/2008, (after the customised computerisation project) it collected L.E. 40 billion (about $\$ 7.6$ billion) [3]. The organisational chart of the ESTD is given in Figure 2. As part of the Central Administration for the Commissioner's Affairs, the General Administration for Change and Development was established in 2004 and was responsible for managing change processes, including the move to PBB.

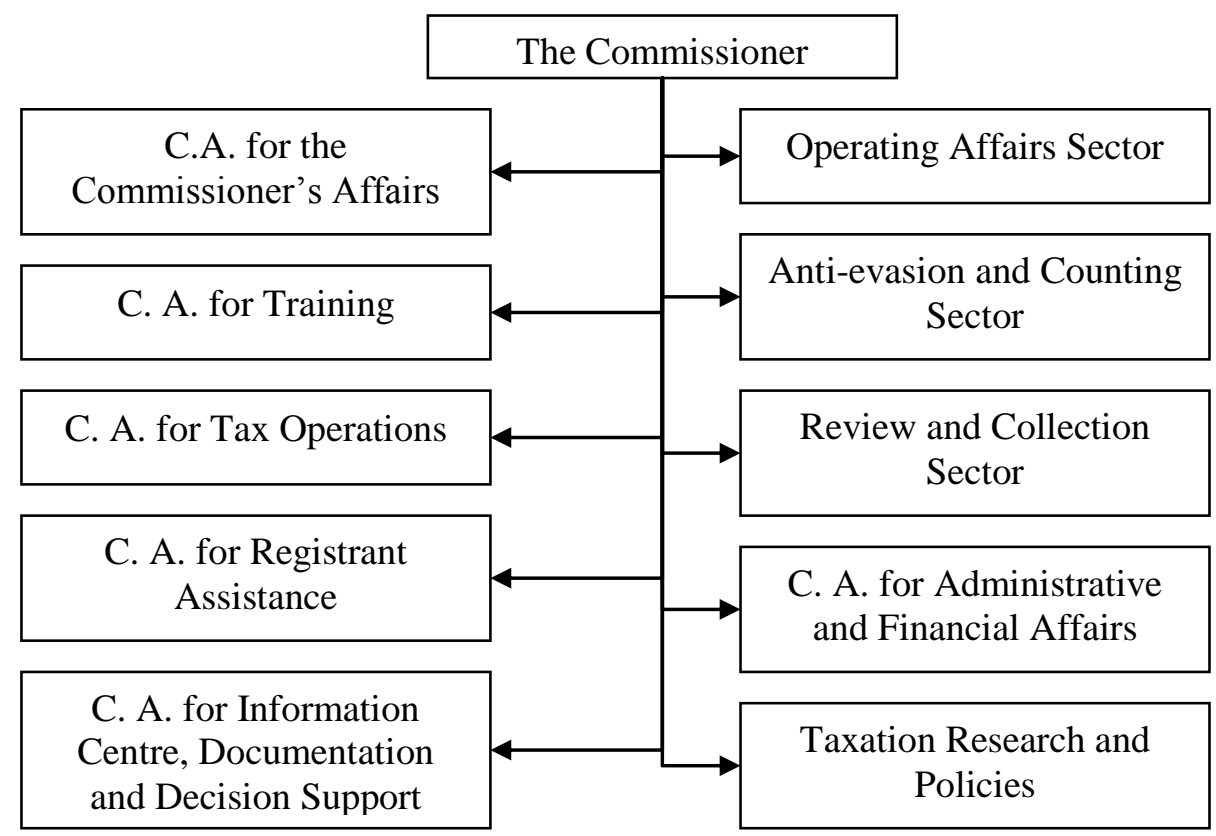

Figure 3: The Organizational Chart of ESTD

Note that C.A. refers to Central Administration 


\section{Case Analysis}

\subsection{The control culture of the existing budgeting process in the ESTD: A top down approach}

ESTD is one of the revenue departments affiliated to the Ministry of Finance. Its budget is a part of the Egyptian government's budget that is governed by Budget Act No. 53 of 1973, amended by Law No. 87 of 2005 . There are three steps for preparing the government's budget in Egypt. Firstly, a budgeting committee is established in each governmental unit to prepare current and capital budget proposal. Secondly, each government unit submits its budget proposal to its related ministry. Then, each ministry consolidates the budget proposals of its related government units and submits its consolidated budget proposal to the Ministry of Finance before the 1st of January each year. Budget proposals of different ministries should be associated with supporting documents that justify their estimates and any changes therein from previous year appropriations. Finally, the Sector of General State Budgeting in the Ministry of Finance prepares the general state budget proposal that consolidates all budget proposals of all ministries after modifying these proposals. After that, the Minister of Finance submits the general state budget proposal to the Parliament to approve.

The budget preparation in ESTD starts with the formation of the budgeting committee. In ESTD, there are two departments, which are permanent members of the budgeting committee, responsible for its budget proposal, the General Administration for Revenues and the General Administration for Budget and Encumbrances (expenditure). The first department is in charge of preparing the estimates of sales tax revenues and following up their collection. The estimates of tax revenues are based on the previous year estimated revenues, expected growth rate and prevailing economic conditions in each industrial sector and service sector. These estimates are prepared for each individual commodity and service separately. A district manager drawing on his past stock of knowledge with previously used budgeting practices, said:

Before the introduction of the sales tax, we were collecting registered companies' budgets in each district and we were using them as a basis for our estimates for tax revenues. If the companies achieved their budgets we would achieve our estimated revenues. 
The second department, the General Administration for Budget and Encumbrances, is in charge of preparing the estimates of expenditures and monitoring the spending of encumbrances and changes therein. Expenditure estimates are prepared using the forms received from the Ministry of Finance at the beginning of each year. These estimates are based on sending requests to all districts and regions to determine their needs for the coming year. After consolidating all these needs, the expenditure estimates are submitted to the Ministry of Finance that decides certain encumbrances after the approval of the Parliament.

The Ministry of Finance normally does not take into account these estimates as their expectation appears to be that government units always overestimate expenditure and underestimate revenue. One regional head expressed these shortcomings as follows:

Estimated revenues are imposed on us from the top. We have no say in that. The Ministry of Finance does not ask for our opinions... However, appropriations sometimes do not meet all our needs. Unsatisfied needs are delayed to the following year(s). For example, there was a building that was intended to be built to absorb the increase in the number of employees. The employees were 800 and became 1800. However, the facilities have not been changed. To reduce expenditures, we are currently using a four-employee table. I mean that every four persons share one table.

The foregoing evinced that middle managers feel powerless as the responsibility for budgets or performance are not devoted and the Ministry of Finance centrally control the allocation of resources. To overcome these limitations in current budgeting practices, some middle managers invent their own solutions to resolve problems encountered. Other managers believe that another set of budgeting practices could be supplied to solve their problems.

The ESTD uses the Egyptian government accounting system according to the Act no. 127 of 1981, amended by Law No. 139 of 2006, in accounting for actual revenues and expenditures and in preparing financial statements. The Egyptian government accounting system is a group of regulations and restrictions that government units have to follow in the implementation of the general state budget, in recording and classifying the financial operations and in preparing the budgetary statements of the government units. The main purpose of this accounting system is to control the execution of the annual budget approved by the parliament. For this control 
purpose, budget and accounting numbers are continuously compared and at the end of the fiscal year variances between the budget (ex-ante) and the accounting (ex-post) figures are reported. Based on monthly statements of trial balance, the central accounts unit in ESTD prepares both interim and annual budgetary statements. The main objective of these statements is to determine the compliance with the budget regarding the appropriations and revenues and to indicate whether these appropriations and revenues were obtained and utilised in accordance with legal and contractual requirements. All the aforementioned budgetary statements are submitted to the Ministry of Finance, the Central Accounting Agency and the Parliament.

\subsection{The Economic crisis and the need for an alternative approach to manage the state budget}

Egyptian authorities faced major economic and fiscal imbalances, a growing budget deficit, high inflation, low savings, low investments, high debt and deteriorating local currency during the 1980s. In 1991, the Egyptian government signed two economic reform and structural adjustment agreements with the World Bank and the International Monetary Fund (IMF) to stabilise the economy via a package of speedy-recovery reforms for the Egyptian Ministry of Finance (MOF) and guarantee fiscal sustainability by balancing public revenues and expenditures. The Egyptian Sales Tax Department (ESTD) was established and applied the General Sales Tax (GST) on 3 May 1991 as part of an overarching Economic Reform and Structural Adjustment Programme sponsored by the World Bank and the IMF (the Income Tax reform followed in 1993). In the first year of operations, the Sales Tax Department registered about 25000 firms.

Towards the end of the 1990s perceptions that attitudes in many key economic activities had become lax lead to the termination of existing World Bank economic reform and structural adjustment programmes in Egypt. Tourism and oil revenues were declining, negatively affected the trade balance. In this context, the World Bank introduced a budget reform programme to the Government of Egypt in September 2000. It recommended replacing the current traditional line item budgeting with a performance-based or results oriented budgeting system. The World Bank introduction of M\&E provided one solution to the crisis situation in which Egypt found itself in. However, the Ministry of Finance had already initiated an IT project, known as the 'Integrated Automation Project' (IAP) in January 2000 that aimed to computerise the government expenditure system throughout the ministry. The new system claims to provide a 
comprehensive, reliable and timely budget and financial management information and helps the Egyptian government to effectively manage the budget and expenditures and control funds [4].

A condition for the World Bank's financing of the IAP was the project to experiment with PBB in the ESTD and then roll out the reforms to the rest of the Ministry of Finance and the Egyptian government. The justification for putting both projects together was made by the Minister of Finance at the time who stated '[i]n the absence of a management information system, reporting and monitoring systems, results-oriented budgeting will be dilapidated. So, a necessary requisite for results-oriented budgeting to survive, flourish and succeed is to automate all government expenditures and revenues' (Hassanein, 2005: 4).

Outcomes or performance based budgets have gained legitimacy at the governmental level and are claimed to produce greater accountability of individuals in governmental projects through transparency of information (Bruijn and Helden, 2006; Chwastiak, 2006). Diamond (2007), an IMF consultant, indicates that depending on how performance is defined, ministry budget holders are then made accountable for performance but if they are made accountable then in return (1) they should be offered more flexibility (2) they should have greater certainty in resourcing (3) they should have incentives for performing well. Aucoin and Heintzman (2000), exploring the dialectics of accountability for performance, identify three purposes of accountability in public service - control, assurance and continuous improvement. Within their discussion, they propose that accounting for outcomes is a compromise between the type of control systems that aim to reduce discretion and eliminate errors, and those that promote devolved, entrepreneurial management saying that 'systems of devolved authority only work well when accompanied by other kinds of restraints' (Ibid: 48).

The World Bank claims that the introduction of PBB into Egypt can provide unique information about the performance of Egyptian government policies, programs, and projects. It can identify what works, what does not, and the reasons why. It also provides information about the performance of the Egyptian government, of individual ministries and agencies, and of managers and their staff (Mackay, 2007: xxi). From the World Bank's point of view, transparency and sound governability of the Egyptian government and its governmental units through the use of PBB might result in, for example, solving the existing problem of relatively low tax revenue collection and productivity. The PBB can better allocate scare resources by 
setting out the aims and goals of each governmental unit, setting realistic targets for the year and then allocating resources on the basis of those targets.

\subsection{The introduction of PBB into the ESTD: the role of World Bank consultants and top officials}

By the end of 2000, the Egyptian Ministry of Finance started to study the World Bank's recommendations before the formal approval at the end of 2002. World Bank experts were involved in the early stages of PBB implementation. In June 2001, they visited Egypt to assess the climate and capacity for building M\&E practices in the Egyptian governmental units. A later visit in March/April 2002 supported the Ministry of Finance in its efforts by conducting a workshop on PBB. In June 2002, a distance learning forum was conducted to raise the awareness of 21 senior officials about $\mathrm{PBB}$ and its possible implementation in Egypt. Another visit complemented by a workshop was made in October 2002 with a specific focus on PBB and building $M \& E$ practices in general. In this visit, local consultants were selected to support the Ministry of Finance on the PBB pilots.

In November 2002, the Egyptian People's Assembly (the Parliament) approved an agreement with the World Bank to design and implement a performance-based budgeting system for the purpose of fiscal reform, expenditure control and enhanced quality public service delivery. A Presidential Decree No. 275 of 2002 was issued to regulate the experimental application of performance-based budgeting in Egyptian governmental units. According to this decree, the Government of Egypt is experimenting with performance-based budgeting in five ministries - the Ministry of Finance, the Ministry of Planning, the Ministry of Industry and Technological Development, the Ministry of Electricity and Energy and the Ministry of Information and Communication.

Whilst the senior governmental officials might have accepted the project of accountability for outcomes to gain World Bank support in a crisis, they are caught by the need to exert some level of accountability for control and assurance. There is evidence though, that at least at the top level of government, PBB was embraced. In assessing Egypt's readiness to introduce results-based $\mathrm{M} \& \mathrm{E}$, the international consultants of the World Bank, Kusek and Rist (2004: 51), identified the former Minister of Finance as a key champion. They mentioned that: 
The Minister of Finance was found to be a key champion for the government of Egypt's move to a results focus. This minister was well versed in the international experience of other countries, such as Malaysia and OECD member countries. The minister underscored the importance of giving increased attention to improving the management of public expenditures by moving forward with a set of pilots to demonstrate how results- based M\&E could be used to better manage budgetary allocations.

The ESTD was noted at this stage as having achieved good progress in implementing the performance-based budgeting as a result of pro-active working parties put in place by the Minister of Finance. A World Bank delegation met with the ESTD's officials in 2002 and the project began shortly afterwards (although informally information systems were already being designed from 2000). In the ESTD, a Principal Committee and a project team were formed following the meeting with the World Bank delegation. The Principal Committee was composed of the Commissioner (the Project Leader and Manager), helped by two consultants (from the Ministry of Finance and the World Bank). In addition six functional area leaders (Heads of Central Administration or General Managers) led area project teams composed of key users and an IT area developer. Each area project team started implementing its set action plan simultaneously. The ESTD's former Commissioner was optimistic about the abilities of ESTD officials to implement $\mathrm{PBB}$ as their version of M\&E. He pointed out that:

The implementation of the programmes and performance-based budget at the Sales Tax Department, as the first governmental unit in Egypt that has started implementing this type of budget reform from the fiscal year 2002/2003. The selection of the Sales Tax Department by the Minister of Finance was a proud moment for all the Sales Tax Department's officials. The Sales Tax Department is qualified to implement this budget reform that requires well-trained employees who are capable of using modern technologies and achieving high quality.

In December 2002, the local consultant of the World Bank was also confident and commented on selecting ESTD by saying:

The Sales Tax Department was selected for implementing the programs-and-performance-based budget because it is characterised by well-qualified employees, top executives who support the budget 
reform and well-paid employees and the availability of integrated information system as well.

From the above quotations, it seems that there are supporting conditions for a successful change project, i.e. a crisis situation, top management support, well-qualified and well-trained staff and the availability of IT facilities. However, the budget reform failed and the IT reform to update the computer system used to collect tax revenues were successful, with significant increases in tax collected. The next section explains the events leading to this outcome.

\subsection{The implementation of PBB in the ESTD: Challenges and Solutions}

\subsubsection{An overview of the computerisation project: the role of IT developers}

In the ESTD, the Committee of Information Systems completely renewed the IT infrastructure and its applications. With co-operation with the Committee of Tax Systems, it also upgraded the general sales tax and collection system (GSTACS), introduced with sales tax in 1991, and developed on-line tax return filing service to help registrants submit their tax return electronically which came into effect from 1/7/2004. It emerged that the computerization was planned informally before 2002, and was ready to start as soon as the monies were available. The GSTACS system had been effectively programmed before the PBB pilot project had begun. The introduction of the computerised tax collection system does however appear to have brought a number of meaningful reforms such as the use of SWIFT systems to aid monetary transfers:

...tax revenues collected by cheques were taking 45 days in the clearance room in the Central Bank. The alternative is to implement SWIFT service. The study revealed that the savings expected would be about L.E. $1 / 2$ million. (Cost Accounting Manager)

Oracle database version (8) was used to automate the existing government accounting system, governed by Law No. 27 (1981) amended by Law No. 139 (2006). Although there was a beneficial move to replace cash-based with accruals based accounting systems, the automation reinforces rather than reforms the traditional line item budget system. An IT developer commented that: 
The automation seeks to speed up performance, increase accuracy, avoid human errors, and reduce time, effort and cost. The government accounting system was analysed, designed and programmed. ... Furthermore, employees were trained on using the computerised system. We automated the old accounting system because all people are used to using it. [the author italics]

This quotation refers to the fact that the IT developers played a central role in automating the existing budgeting rules and routines and reproducing the traditional system of accountability that relies primarily on centralized command and control systems, focussing exclusively on securing compliance with input control and process without holding individuals accountable for their individual performance.

Whilst these committees were overseeing the computerisation of tax collection and the underlying accounting systems, the Committee for Planning, headed by the head of General Administration for Planning, became responsible for developing the PBB system in ESTD. The Planning Department in ESTD had been established in the 1990s to prepare annual plans for all regions and districts designed to achieve annual estimated tax revenues. As a result, this department took the responsibility for the new budgeting system and its members became the key members of the committee set for this purpose. The 'new' performance reporting system was automated using MS Excel files. All districts and regions prepare performance reports using Excel files and use the Intranet to exchange the files between the districts and regions and the headquarters in Cairo but in practice has only been used in Cairo. In addition, software called 'performance standards system' was developed using Power Builder and Sybase Database as programming tools. However, this software was never used. In other words, the PBB project resulted in incremental changes to existing monitoring and evaluation structures of middle managers in the ESTD.

The Committee for Planning reformulated the ESTD's mission, principles, strategy, policy and methodology and added three new performance indicators (i.e. productivity, quality and results) to existing efficiency and effectiveness measures. A researcher in the General Planning Department pointed out:

We have been preparing the annual plan and have been using efficiency and effectiveness measures before implementing the 
performance-based budget. This helped us to absorb the idea and complete its components. Furthermore, we depend on the existing organisational structure to set programmes for each region and district.

This reflects a slight development in the existing planning system adopted by ESTD before the introduction of PBB. However, it does not affect existing budgeting routines. What is developed is a system of performance reporting identifying different activities and measuring changes within them, rather than a full system of PBB [5]. Performance data are developed independently of the line item budget and control accounts, and cost figures have not been attached thereto. Reviewing data collected from meetings and other encounters though, the adherence to line item budgeting was more than just a problem with systems programming.

\subsubsection{Persistence of line item budgeting: The role of the budget law and the Ministry of Finance}

In 2004, a number of meetings were held by the Principal Committee to review progress on PBB to date. A key meeting with World Bank officials was due in September 2004 (observed by the researcher) found that little progress had been made. The Ministry of Finance Consultant (a university professor) asked the following questions:

We need to have a performance-based budget for ESTD before the World Bank meeting on 12/09/2004. Is that possible? ...The estimated revenues for 2004/2005 are L.E. 26 billion and the appropriations (chapters 1 and 2) are L.E. 260 million. What are the programmes planned to achieve the L.E. 26 billion? ... We need a programming and performance budget with L.E. 260 million to collect L.E. 26 billion. If you continue using the old system, you would achieve only L.E. 22 billion (the previous year actual revenues). What are the means to increase the revenues by L.E. 4 billion?

Now, the consultant is clearly using the language of PBB - identifying an outcome and looking for what resources need to be allocated to achieve the outcome. However, the answers received to these questions are revealing. A budgeting accountant responded to the Minister of Finance Consultant's questions in a way that indicates some resistance as he has not seen a structural change to support the move towards the new budgeting technique: 
The use of performance-based budget is currently difficult because the whole government budget is a line-item budget. So it would be difficult that some government units use line item budgets and other units use performance-based budgets.

This was supported by general managers who stated:

We currently use the line-item budget. If the Ministry of Finance wants us to implement the performance-based budget, it would send the appropriate forms to fill. (The General Manager for Budgeting and Encumbrances)

The Ministry of Finance should itself implement the performancebased budget. If it has not implemented the budget reform, the current situation would continue for a long period and there would not be integration. (The General Manager of Planning)

From the above, the Ministry of Finance as an external structure is seen by middle managers as an obstacle to the successful implementation of PBB in the ESTD. It appears that at this stage, two years into the project, the desirability of outcomes based budgeting has not yet been transmitted and that there is internal opposition to the idea of the ESTD being a pilot for the Ministry as a whole. However, the consultant responds back in a manner that indicates he is applying lessons learned by the World Bank:

The implementation will be gradual and will take from 5 to 10 years, like Malaysia. We can not change the current budgeting system... What we need is a performance-based budget for $2004 / 2005$, together with the state budget before $12 / 09 / 2004 \ldots$ We need to re-allocate the line-item budget for 2004/2005 to programmes according to responsibility centres. What do you need to do this?

The underlying problem begins then to emerge. The accounts to control and record distributions of money have not been established on a programme basis nor sub-divided into performance units. It seems clear PBB was perceived by middle managers and other senior officials as a complementary tool to the current line item budget rather than a replacement to it. According to the Budget Act No. 53 of 1973, amended by Law No. 87 of 2005, the government units are required to set their activities in the form of programmes and prepare programme budgets for their 
activities in addition to the current and capital budgets. As this law enforced by the Ministry of Finance is an "irresistible external influence", the separation of performance indicators from budgeting seems legitimate. The accountability for control and assurance affects the Egyptian government's decision to use PBB as a complementary tool, rather than the primary driver for management control. The difficulty in the operationalisation of PBB is evident in the following problems.

\subsubsection{The problem of budget estimates}

The Budget Act No. 53 (1973), amended by Law No. 87 (2005), requires the current estimation base of both revenues and expenditures using the results of prior three years as a base for predicting the coming year revenues and expenditures. However, there are no clear guidelines for preparing performance-based budget estimates. The Minister of Finance Consultant asked:

The estimated revenues for 2004/2005 are L.E. 26 billion. There is a planned increase in revenues with L.E. 4 billion this year. What are the spending requirements to achieve this increase?

The General Manager of Planning Department suggests, working on a contrasting logic to the consultant:

We can analyse the actual expenditures for the previous year (2003/2004). The fundamental appropriations at the beginning of the year were L.E. 215 million and the actual expenditures at the end of the year were L.E. 275 million. Thus there was L.E. 60 million deficit or additional appropriations.

The Consultant tries to bring the reasoning back to being forward looking:

Is there a relationship for such increase with other variables such as the increase in collected revenues or the increase in the workforce? Or is it just coincidence? What were the reasons for the additional appropriations and the means used to fund them? We can assume that the increase in expenditures would be the same as the prior year (L.E. 60 million).

To which a general manager responded:

There were a lot of reasons for such increase and we cannot classify them into categories. In addition, your suggestion means 
that there is an official recognition of the additional appropriations and that the costs have to increase. We can use the basic appropriations for 2004/2005 (L.E. 260 million) as a minimum estimation.

The Minister of Finance Consultant then suggested:

The budget in Egypt is based on actual basis. What it is supposed to do is show the labour in Egypt as fixed cost except incentives... You can start with prior year actual expenditures (L.E. 275 million) as an initial basis for estimation and, then, add $10 \%$ the annual increase in wages and salaries as an inevitable increase.

These discussions indicate that there was no agreement on a unified basis for preparing the performance-based budget or even the starting point for such estimates. Should these estimates be based on current year appropriations and expected additional appropriations by an amount equal to prior year additional appropriations? Or should previous year actual expenditures be modified by only inevitable increases such as the $10 \%$ annual increase in wages and salaries? Accounting for outcomes that identifies the activity and then a (reduced) resource allocation again appears to be receding. The Budget Law does not provide any guidelines which make it difficult to prepare acceptable estimates.

\subsubsection{The Cost Allocation Problem}

Another issue in the implementation of PBB in the ESTD is the problem of cost allocation. The Minister of Finance Consultant asked the following question:-

Can you convert the line item budget for 2004/2005 into a performance-based budget?

The answers to this question - the pressing problem before the September 2004 meeting with the World Bank - elicited a range of conflicting responses:

We prepared the current year budget according to the object of expenditure classification as we received the old forms from the Ministry of Finance. We do not have the functional classification of expenditures. (The General Manager for Budgeting and Encumbrances) 
We have the functional classification of expenditures (chapter 1 and 2) on the costing system but for the previous year 2003/2004. We have not prepared the functional classification for the current year because we have not received cost data reports from some districts. (Cost Accounting Department Manager)

The Minister of Finance Consultant then commented:

Is it possible to prepare both cost classifications together (by functions and by object of expenditure), which allow for allocating the total appropriations to different types of expenditures and different responsibility centres at the same time?

The next response by the World Bank Consultant is significant:

We are interested in the costs of programmes and their activities. If we get these figures, that's enough and there is no need for relating them to the object of expenditure classification.

The Manager of Cost Accounting Department commented:

We actually analysed the previous year expenditures according to both cost classifications. The costing software is able to do so.

The question arises from these exchanges: what exactly was PBB meant to achieve? Did the World Bank consultant imply that programmes and activity information was enough for now, or for the whole project? What was the long term aim for accountability by outcomes? There was a final, more fundamental problem though that emerged from discussions - who was responsible for performance evaluation?

\subsubsection{The Problem of Performance Evaluation}

Assigning the responsibility for performance evaluation is another issue in implementing PBB. The MoF Consultant, following World Bank recommendations, stated that there should be a totally separate and independent department for performance evaluation. There appears to have been some resistance to performance evaluation taking place and the decision as to who would be responsible for it was never made. Recommendations that it should be the Planning Department which was in charge of performance measurement ignited a debate about auditability and IT. One IT general manager stated that 'performance evaluators should have sufficient knowledge of IT' and a developer expanded the problem by 
saying 'currently, persons who audit our work, do not understand in IT. They report only on computers' problems such as the breakdown of a printer or a network'. The World Bank Consultant disagreed:

Auditors evaluate results. It is not necessary for auditors to understand IT. Auditors can get help from some experts when they do not have such expertise. The Central Agency for Accountability should be responsible for performance evaluation in the organisation as it has experts in different financial, administrative and technical areas.

The MoF Consultant agreed with this suggestion, saying:

The Central Agency for Accountability has permanent auditors within organisations. It is a good idea for performance evaluators to live in the field... There should be performance evaluation units in each district and each region. Moreover, there should be different experts in each functional area such as tax and information systems.

This exchange highlights the fact that accountability for outcomes became simplified into a more mechanical discussion of auditability and structures, emphasising the accountability for control and assurance internalised by senior Egyptian governmental officials. However, the danger of simplification can be seen the other way which makes middle managers show some resistance to the idea of auditability of performance. In The Audit Society Power (1997: 98) warned that 'the imposition of audit and related measures of auditable performance leads to the opposite of what was intended, i.e. it creates forms of dysfunction for the audited service itself'.

\subsection{The termination of $P B B$ implementation in the ESTD: The departure of} key champions

Towards the latter part of 2005 and at the beginning of 2006, dramatic changes in the Egyptian government have led to stop working at the PBB project. Performance based budgeting was experimented with and then abandoned by a new Minister of Finance, although some level of performance reporting within ESTD was achieved. The decision to abandon PBB in the ESTD was associated with shifts in the interests and underlying power distributions that have supported and legitimated the institutionalization and sustainability of PBB arrangements. In 2005, the Budget Law was amended to require the implementation of $\mathrm{PBB}$ as a complementary tool. By the end of 2005, the former Minister of Finance 
(the key champion and the PBB sponsor and initiator) resigned. This put an end to any future development of the PBB system in ESTD or any other governmental unit. In this regard, the World Bank consultants, Kusek and Rist (2004), argue that 'the role of a political champion is key to ensuring the institutionalization and sustainability of results-based M\&E systems' ( $P$. 21) and 'the presence of a national champion can go a long way toward helping a country develop and sustain M\&E systems' (P.33). However, the key Egyptian champion had been replaced by 2005 and the new Minister of Finance has changed his priorities and cancelled the PBB project.

In April 2006, the Egyptian Government announced a plan to integrate the Income and Sales Tax Department into a single, unified Egyptian Tax Authority (USAID, 2006). Other governmental units which had begun performance-based systems in c.2002 have since abandoned them through political upheaval and changing priorities. In 2007, the former ESTD Commissioner (the PBB Manager in ESTD) resigned and a new Commissioner was appointed. The new Commissioner of ESTD announced on 11 February 2008 that he is going to replace PBB with a balanced scorecard system to link incentives to performance indicators, saying that he no longer believes in the benefits of PBB. However, there is no evidence as yet that the BSC has been implemented.

There is an interesting document published on the World Bank website in which the Minister of Finance who resigned looks back on the attempt to implement $\mathrm{PBB}$ in the Ministry. He appears quite belligerent after the experience:

Never issue a law or decree that would force a move from input to outcomes budgeting on the throats of disinterested parties. Unless you lobby and buy-in the interested stakeholders while convincing them of the fruits of bringing down the budget deficit and bringing welfare to the citizen first, success can be a high risk venture. From my personal point of view, the phrase that should win the day in the move towards results-orientation: 'Bought-in stakeholders FIRST; sustained, incentive-based M\&E systems SECOND; and legislation comes LAST.' (Hassanein, 2005)

This view of the former Minister of Finance indicates that the amendment of the Budget Law to force the move from line item budgeting to PBB was wrong because buy-in on the ground was needed. As seeing is believing, middle level officials and other stakeholders were not convinced that PBB would be materialized in reality. One district manager commented that: 
There is a contradiction between imposing estimated revenues on us from top to down and preparing a performance-based plan from down to top. This is not consistent with the accountability principle. The heads of regions and the managers of districts should participate in setting their own budgets to be able to achieve them. The major disadvantage of the performance-based budget implementation so far is that it has not been associated with decentralising the authorities of preparing budgets to the heads of regions and the managers of districts.

The evidence before middle managers suggests that it is highly improbable that they will have responsibility for performance or even for participation in budgets or target setting. So whilst middle managers may be partly gripped by the principles of $\mathrm{PBB}$, pragmatically they saw no movement toward this and any propulsion toward change that the rhetoric might offer appears dissipated by lack of evidence that real change was about to occur. Middle managers has the physical capacity to resist the external influence (i.e. the Budget Law and the Ministry of Finance) but feels that they do not have the ability to resist as expressing opposition to the exercise of power does not come with job security. The World Bank may have been disappointed but, as elsewhere, accept for a time that this is a learning experience (Mackay, 2007; Schiavo-Campo, 2005).

\section{Discussion}

The World Bank claim that 'a good understanding among key [Egyptian] government ministers of the potential benefits of M\&E' (Mackay, 2007: 61) has been developed and the process of PBB implementation 'has been entirely top-driven' (WBOED, 2004: 59). They also believe that the 'efforts to institutionalize M\&E in Egypt have been substantially frustrated by midlevel officials' (Mackay, 2007: 61) due to 'the weak level of cooperation and even resistance encountered at lower levels within agencies' (WBOED, 2004: 18). This paper questions these beliefs using an intensive case study in the ESTD, one of the agencies involved in the PBB implementation, to understand the reasons behind the failure of PBB implementation in Egypt and explain why PBB did not materialize.

The researcher' findings reveal that senior Egyptian governmental officials disguise their compliance with the World Bank's conditions to implement PBB. They promised to produce a new system of accountability for control and assurance that manages to outputs and outcomes, empowers middle 
managers to be entrepreneurial and assesses their individual performance. However, the centralized command and control system of accountability was reproduced. Resistance to management accounting change as adherence to earlier procedures or routines is observed in previous studies (Burns and Scapens, 2000; Granlund, 2001; Burns et al., 2003).

A review conducted by the World Bank found that international experts had not paid sufficient attention to 'defining specific performance indicators in the agencies, the incentives facing staff and the need for change management initiatives' (WBOED, 2004: 18). These matters were left to local consultants who direct the PBB implementation process. The new knowledge embedded in PBB does not appear to have been transferred to local consultants, who took a pragmatic approach to the project, drawing on their existing stock of knowledge including local laws and regulations. The outcomes of this were no real change to existing budgeting practices and appears to have let to the view that 'the support of a group of key ministers for M\&E has been substantially frustrated by sceptical mid-level officials' (Mackay, 2007: 55, 56).

In the absence of direct involvement of international experts in the implementation process of $\mathrm{PBB}$, the monies were spent to automate the traditional line item budgeting system that secures compliance with input control and process and does not assess individual accountability. The departure of key champions, both the former Minister of Finance and the former ESTD's Commissioner, was just a formal recognition that the game is over. Ironically, however, the underpinning aim of investment to increase revenue that could go towards the alleviation of poverty was achieved through the computerisation of the collection of sales tax, with tax collected almost doubling in the period 2002-2008.

The middle managers who were blamed by the World Bank were the real supporters of PBB. They sought to push accountability down to lowest levels in the hierarchy by giving them greater freedom to manage and more accountability for continuous improvement. What middle managers observed in reality is the reproduction of a system that centrally controls the management of inputs and process and does not seek to hold them accountable for their individual performance. From the point of view of middle managers, the government ministers, the Ministry of Finance and the Budget Law that legitimised the use of PBB as a complementary tool are "irresistible external influences". Granlund (2001) found a similar finding where new rules and routines are introduced without corresponding institutional change. The inattention or even resistance by mid-level 
officials observed by the World Bank was for the actions of senior Egyptian governmental officials that reproduced existing budgeting rules and routines, not for the core concepts of PBB.

The World Bank appears to have been gripped by the principles of accountability for outcomes. However, performance or outcomes based budgeting in government appears to be problematic, with no one clear good example being in place of a whole Nation run on such lines. Transparency is problematic as a goal, as shown amply by Roberts (2009) and accountability for outcomes is tempered by pressures for accountability for control and assurance from stakeholders, as shown by Aucoin and Heintzman (2000). Monitoring and evaluation systems take time and sometimes radical change to achieve (Mackay, 2007). In the meantime, inability to achieve fully conditionality is waived where some step toward accounting and accountability for outcomes (the use of PBB as a complementary tool for example) is made (World Bank, 2007). Failures to develop suitable outcomes based budgeting and appraisal systems, such as that in the ESTD, can be interpreted in terms of the failure of the Egyptian government to deliver its promises to give local managers more management freedom to perform and more individual accountability.

\section{Contributions and Conclusions}

One contribution of this study is that the analysis presented here identifies the reasons for resistance to change in management accounting practices, PBB (see also Scapens and Roberts, 1993; Burns, 2000; Granlund, 2001; Burns et al., 2003; Dambrin et al., 2007; Lukka, 2007; Hyvonen et al., 2009; Macintosh et al., 2009; Kilfoyle and Richardson, 2011; Adhikari et al., 2013; Brunt, 2014; Robalo, 2014; Malmmose, 2015). It offers an alternative interpretation of the failure of the Egyptian project for monitoring and evaluation to that published by the World Bank (WBOED, 2004; Hassanein, 2005; Schiavo-Campo, 2005). Whereas the Bank's reports blame middle management intransigence for the failure to implement PBB, an alternative explanation is that middle managers and the World Bank shared the same benefits of PBB but that senior management and politicians failed to mobilise this, reproducing existing budgeting rules and routines and failing to manage the change process across all the elements of the organisation, including providing requisite changes in legislation. Middle managers were not resistant toward performance based budgeting as such, but experience had made them sceptical of senior managements capability to effect change. The case as interpreted here could act as feedback into the acknowledged learning experience of the Bank (Mackay, 2007; World Bank, 2007). 
Finally, the study contributes to the question raised by Power (2000) and stated in the introduction: how well do the concepts of the audit society travel? From this case, middle managers are receptive to the concept of accountability for outcomes, whatever form of signification or practice it takes. Resistance in this case is related to relations between levels of management. The interpretation offered here may provide some insight into why individuals or groups are gripped by the practices of performance measurement and why monitoring and evaluation becomes accepted and embedded. Further case studies which monitor the work of the World Bank in its M\&E capability building project over the next few years from an accounting and control perspective would contribute to our understanding of how global notions of accountability continue to be crafted by supranational agencies. Further critical assessment of the limits of accountability of outcomes as a desirable basis for governmental accounting and its application will also be needed as notions of accountability as yet unproven in developed countries are diffused to developing countries.

The obvious limitations apply to the study, in that it is a single case study. Findings have support from other studies but are not generalisable. A further limitation is that data from the World Bank is purely documentary, with the exception of some limited access to their consultants involved in the project, whereas interview data from World Bank representatives would have been useful. It should be noted that the analysis of this case was developed more fully once the World Bank began publishing reports on conditionality, M\&E and the Egyptian Project from 2007 that enabled the author to contextualise the data collected more fully.

\section{Endnotes}

[1] 'In 2002, the Bush Administration announced it would contribute \$300 million over three years (\$100 million in FY2004, \$200 million in FY2005) if the World Bank agreed to adopt specific steps to improve accountability and better measure the results of Bank-funded operations.' (Weiss, 2005 p.6 Note 23)

[2] The World Bank has since revised its policy of conditionality (World Bank, 2007) but it remains a key factor in this study.

[3] Under the GST legislation, manufacturers, importers and service providers with annual turnover of L.E. 54000 or more, while wholesalers and retailers with an annual turnover of L.E. 150000 or more, are required to collect the GST from their customers and remit such amounts to Sales Tax Department. According to the legislation, GST is levied on goods that are locally manufactured or imported unless such goods are specifically 
exempted. The GST is also levied on a number of specified services. Exported goods and services are taxed at a zero rate, whereas the standard GST rate levied on taxable goods is $10 \%$ and $5 \%$ for taxable services.

[4] Two phone conversations were conducted with the IAP Director and the Minister of Finance's consultant on 23 November 2004 to explore more details about this project.

[5] Performance-based budgeting goes beyond the performance reporting system. The identification of programmes and the measurement of changes therein are set forth on a cost basis so that performance costs are equal to total costs for budgetary purposes. 


\section{References}

Adhikari, P., Kuruppu, C. and Matilda, S. (2013), "Dissemination and institutionalization of public sector accounting reforms in less developed countries: A comparative study of the Nepalese and Sri Lankan central governments", Accounting Forum, Vol. 37, pp: 213-230.

Aucoin, P. and Heintzman, R. (2000), "The Dialectics of Accountability for Performance in Public Management Reform", International Review of Administrative Sciences, Vol. 66, pp: 45-55.

Beckett-Camarata, J. (2009), "Local government measurement and use of performance accounting and financial reporting data in planning and budgeting decision support: A multi-case study", Public Performance \& Management Review, Vol. 33 No. 2, pp. 255 - 265.

Berry, A.J. and Gray, I. (2000), "Some Things in Moderation: A Case Study of Internal Audit", International Journal of Auditing, Vol. 4, pp. 51 - 69.

Bowerman, M., Raby, H. and Humphrey, C. (2000), "In Search of the Audit Society: Some Evidence from Health Care, Police and Schools", International Journal of Auditing, Vol. 4, pp. 71-100.

Breul, J.D, and Moravitz, C. (2007), Integrating performance and budgets: the budget office of tomorrow, Maryland: Rowman and Littlefield.

Bruijn, H. and Helden, J. (2006), “A Plea for Dialogue Driven PerformanceBased Management Systems: Evidence from the Dutch Public Sector", Financial Accountability and Management, Vol. 22 No. 4, pp. 0267-4424.

Bruns, H. (2014), "Accounting change and value creation in public servicesDo relational archetypes make a difference in improving public service?", Critical Perspectives on Accounting, Vol. 25, pp. 339-367.

Burns, J. and Scapens, R.W. (2000), "Conceptualising Management Accounting Change: An Institutional Framework", Management Accounting Research, Vol. 11, pp. 3-25.

Burns, J., Ezzamel, M., Scapens, R.W. (2003), The Challenge of Management Accounting Change: Behavioural and Cultural Aspects of Change Management, London, UK: Elsevier Ltd. 
Burns, J. (2000), "The Dynamics of Accounting Change: Interplay between New Practices, Routines, Institutions, Power and Politics", Accounting, Auditing and Accountability Journal, Vol. 13 No. 5, pp. 566-596.

Chand, P. and White, M. (2007), "A Critique of the Influence of Globalization and Convergence of Accounting Standards in FIJI", Critical Perspectives on Accounting, Vol 18, pp. 605-622.

Chwastiak, M. (2006), "Rationality, Performance Measures and Representations of Reality: Planning, Programming and Budgeting and the Vietnam War", Critical Perspective on Accounting, Vol. 17, pp. 29-55.

Cooper, C., Neu, D. and Lehman, G. (2003), "Globalisation and its Discontents: A Concern about Growth and Globalization", Accounting Forum, Vol. 27 No. 4, pp. 359-364.

Dambrin, C., Lambert, C. and Sponem, S. (2007), "Control and Change Analysing the Process of Institutionalisation", Management Accounting Research, Vol. 18, pp. 172-208.

Diamond, J. (2002), Budget System Reform in Transitional Economies, Working Paper WP/02/22, International Monetary Fund, Fiscal Affairs Department.

Diamond, J. (2007), Overview of Performance Budgeting, Presentation: Performance Budgeting Seminar, ITP, Pune October 1-5 2007.

Graham, C. and Neu, D. (2003), "Accounting for Globalisation", Accounting Forum, Vol. 27 No. 4, pp. 449-471.

Granlund, M. (2001), "Towards Explaining Stability in and Around Management Accounting Systems", Management Accounting Research, Vol. 12, pp. 141-166.

Granlund, M. and Lukka, K. (1998), "It's a Small World of Management Accounting Practices", Journal of Management Accounting Research, Vol. 10, pp. 153-179.

Hassanein, M (2005), "The Egyptian Experience in Outcomes-Based Management", available at: www.worldbank.org/ieg/outcomesroundtable/docs/Egypt_Outputs_to_Outc omes.pdf (accessed 07 April 2015). 
Hughes, R. (2005) "Is audit research? The relationships between clinical audit and social research", International Journal of Health Care Quality Assurance, Vol. 18 No. 4, pp. 289-299.

Hyvönen, T., Järvinen, J., Pellinen, J. and Rahko, T. (2009), "Institutional Logics, ICT and Stability of Management Accounting", European Accounting Review, Vol. 18 No. 2, pp. 241-275.

Kamarck, E.C. (2003), Government Innovation around the World, Ash Institute for Democratic Governance and Innovation John F. Kennedy School of Government Harvard University, Boston, MA.

Khalifa, R., Sharma, N., Humphrey, C. and Robson, K. (2007) "Discourse and Audit Change: Transformations in Methodology in the Professional Audit Field", Journal:Accounting, Auditing and Accountability Journal, Vol. 20 No. 6, pp. 825-854.

Kilfoyle, E. and Richardson, A. (2011), "Agency and Structure in Budgeting: Thesis, Antthesis and Synthesis", Critical Perspectives on Accounting, vol. 22, pp. $183-199$.

Kusak, J. Z. and Rist, R.C. (2004), Ten Steps to a Results-Based Monitoring and Evaluation System: A Handbook for Development Practitioners, World Bank, USA.

Lukka, K. (2007), "Management accounting change and stability: loosely coupled rules and routines in action", Management Accounting Research, Vol. 18, pp. 76-101.

Macintosh, N., Shearer, T. and Riccaboni, A. (2009), "A Levinasian ethics critique of the role of management and control systems by large global corporations: The General Electric/Nuovo Pignone example", Critical Perspectives on Accounting, Vol. 20 No. 6, pp. 751-61.

Mackay, K. (2006), Institutionalization of Monitoring and Evaluation Systems to Improve Public Sector Management, Working Paper Series 15, The World Bank ECD, Washington.

Mackay, K. (2007), How to build M\&E systems to support better government, The World Bank, Washington D.C. 
Malmmose, M. (2015) "Management accounting versus medical profession discourse: Hegemony in a public health care debate - A case from Denmark", Critical Perspectives on Accounting, Vol. 27, pp. 144-159.

Manson, S., McCartney, S. and Sherer, M. (2001) "Audit Automation as Control within Audit Firms", Accounting, Auditing and Accountability Journal, Vol. 14 No. 1, pp. 109-130.

Marti, C. (2013) "Performance budgeting and accrual budgeting: A study of the United Kingdom, Australia and New Zealand", Public Performance \& Management Review, Vol. 37 No. 1, pp. 33-58.

Neu, D., Gomez, E.O., Ponce de León, O.G., and Zepeda, M.F. (2002) "Facilitating' globalization processes: Financial technologies and the World Bank", Accounting Forum, Vol. 26 No.3\&4, pp. 271-290.

Nolke, A. (2005) "Introduction to the Special Issue: The Globalization of Accounting Standards", Business and Politics, Vol. 7 No. 3, pp. 1-7.

Ouibrahim, N. and Scapens, R. (1989) "Accounting and Financial Control in a Socialist Enterprise: A Case Study from Algeria", Accounting, Auditing and Accountability Journal, Vol. 2 No. 2, pp. 7-28.

Power, M. (2000) "The Audit Society - Second Thoughts", International Journal of Auditing, Vol. 4, pp. 111-119.

Power, M. (1994), The Audit Explosion, London, DEMOS.

Power, M. (1997), The Audit Society: Rituals of Verification, Oxford University Press, Oxford.

Power, M. (2003) "Evaluating the Audit Explosion", Law and Policy, July, pp. 185 - 202.

Robalo, R. (2014), "Explanations for the gap between management accounting rules and routines: An institutional approach", Spanish Accounting Review, Vol. 17 No. 1, pp. 88 - 97.

Roberts, J. (2009), "No One is Perfect: the Limits of Transparency and an Ethic for 'Intelligent' Accountability", Accounting, Organization and Society, Vol. 34, pp. $957-970$. 
Scapens R.W. (1990), "Researching management accounting practice: The role of case study methods", The British Accounting Review, Vol. 22 No. 3, pp. 259-281.

Scapens, R. W. and Roberts, J. (1993) "Accounting and Control: A Case Study of Resistance to Accounting Change," Management Accounting Research, Vol. 4, pp. 1-32.

Schiavo-Campo, S. (2005), Building Country Capacity for Monitoring and Evaluation in the Public Sector: Selected Lessons of International Experience, ECD Working Paper Series No.13, The World Bank, Washington D.C.

Sikka, P. (2003), "The Role of Offshore Financial Centres in Globalization.", Accounting Forum, Vol. 27 No. 4, pp. 365-399.

Unerman, J. (2003), "Enhancing Organizational Global Hegemony with Narrative Accounting Disclosures: An Early Example", Accounting Forum, Vol. 27 No. 4, pp. 425-448.

Unites States Agency for International Development (USAID) (2006), "USAID Assistance in Fiscal Reform: Comprehensive Tax Reform in Egypt", USAID, USA, available at http://www.fiscalreform.net/pdfs/egypt_comprehensive_tax_reform_2006.p df (accessed 07 April 2015).

The World Bank's Operation Evaluation Department (WBOED) (2004), "Evaluation Capacity Development: OED Self-Evaluation", June, The World Bank, Washington, D.C.

Weiss, M.A. (2005), "The World Bank: Changing Leadership and Issues for the United States and Congress", Congressional Research Service Report $R S 22029$, The Library of Congress, Washington.

World Bank (2001), Report No. 22397-EGT: Egypt Social and Structural Review June 2001, World Bank Social and Economic Development Group Middle East and North Africa Region, Washington D.C.

World Bank (2007), Conditionality in Development Policy Lending, Operations Policy and Country Lending, World Bank, Washington D.C. 